\title{
Longitudinal Care Evaluation in Child Healthcare
}

\author{
Dandara Rayssa Silva de Souza1, Tainara Lôrena dos Santos Ferreira1, \\ Fábia Barbosa de Andrade ${ }^{2}$
}

${ }^{1}$ Undergraduate Nursing in the Health Sciences School (FACISA), Federal University of Rio Grande do Norte (UFRN), Santa Cruz/RN, Brazil

${ }^{2}$ Health Sciences School (FACIS), Federal University of Rio Grande do Norte (UFRN), Santa Cruz/RN, Brazil

Email: dandara_rayssa@hotmail.com, tainara_lorena@hotmail.com,fabiabarbosabr@yahoo.com.br

How to cite this paper: de Souza, D.R.S., dos Santos Ferreira, T.L. and de Andrade, F.B. (2016) Longitudinal Care Evaluation in Child Healthcare. Open Journal of Nursing, 6, 902-909.

http://dx.doi.org/10.4236/ojn.2016.610087

Received: March 26, 2016

Accepted: October 25, 2016

Published: October 28, 2016

Copyright $\odot 2016$ by authors and Scientific Research Publishing Inc. This work is licensed under the Creative Commons Attribution International License (CC BY 4.0).

http://creativecommons.org/licenses/by/4.0/ (c) $\underset{\mathrm{EY}}{\mathrm{i}}$ Open Access

\begin{abstract}
Objective: To evaluate the essential attribute of Primary Health Care, longitudinal care, care directed at children from birth to two years old. Methods: This is a descriptive and exploratory study of evaluative character and quantitative approach, conducted with parents/caregivers of 186 children, younger than two years old, patients of primary health care services in the city of Santa Cruz/RN, Brazil. For data collection, the instrument Primary Care Assessment Tools (PCA Tools) was used, and the results of the questions dealing with longitudinal attribute were evaluated. The data were stored and processed in Statistical Package for Social Sciences (SPSS). The study was approved by the Research Ethics Committee of the Health Sciences School of Trairí, under number 348896. Results: The mean age of children in months was $8.21 ; 84.4 \%(n=157)$ were assisted by the same doctor/nurse every time; in $81.7 \%(\mathrm{n}=152)$ of cases the doctor/nurse know the full medical history of the child; $73.7 \%(\mathrm{n}=137)$ answered that the professional know their child more as a person than just as someone with a health problem; $48.9 \%(\mathrm{n}=91)$ stated that the doctor/nurse do not know their family very well; $86.6 \%(\mathrm{n}=161)$ reported finding the doctor/nurse understands what is saying or questioning; $96.2(\mathrm{n}=179)$ of respondents said the doctor/nurse answers the questions so that they understand; $96.2 \%$ ( $\mathrm{n}$ $=179$ ) of the interviewed said they feel comfortable telling the concerns or problems of their child to the doctor/nurse; 66.7\% $(n=124)$ claimed that they would not change the service/doctor/nurse to another health service. Conclusion: It is concluded that the attribute was well rated by the mothers of children seen in primary health care services and that they can establish good communication and relationship with the health professionals who treat their children.
\end{abstract}

\section{Keywords}

Primary Health Care, Child Health, Health Services Evaluation 


\section{Introduction}

The Primary Health Care (APS) is the set of functions that coordinate the input in health systems, basing its importance for the development of disease and injury prevention activities, as well as promotion, protection, and recovery of health, working together with the other levels of assistance [1]. The Family Health Strategy (ESF) is one of the proposals of the Ministry of Health to strengthen primary health care in Brazil, prioritizing the actions of the APS integral and continuously centered on the family and not just the individual [2].

The Basic Units of Health set (UBS) and ESF configure the care services that integrate primary health network within the public system in Brazil, entitled Health Unic System (SUS). In UBS healthcare professionals need to perform the assistance respecting a set of attributes: first contact access, longitudinality, coordination and integrality.

The structure of these attributes, this study will be made around the longitudinality, which consists in building a personal relationship of long stay between health professionals and users in your community, and this relationship the link that allows increased knowledge about patients by professionals and vice versa. In addition, the promotion of longitudinality is related to various benefits such as reduced demand for services, the most effective preventive measures, greater ease in identifying the problems of patients and total spending with lower health [1]. It emphasizes the importance of effective longitudinality the actions of APS by the fact that it provides a better service, as it allows the professionals develop a more accurate and effective plan for each user/patient [3].

The effective longitudinal care in the context of primary care happens by building a personal relationship of long stay between health professionals and patients in their health units; this relationship is the link that allows increased knowledge about patients by professionals and vice versa [1].

Thus, longitudinal care constitutes a fundamental attribute that characterizes the APS since in its configuration, ESF, and UBS work from the perspective, so that the registered population can be cared in the same place, by the same team and by the same professional during his life, while living there.

The field of child health, above all, deserves qualification in public health care as it is during the childhood that several human potential is determined so that the disturbances of that stage influence the development of negative characteristics to the individual and society [3] [4].

On the longitudinal exercise in the child health care, this attribute is implemented necessarily from the contact established between parents/caregivers and health professionals for the knowledge of history and the child's family context [5]. Therefore, it optimizes the monitoring of growth and development in APS.

For these reasons, and understanding the importance of the child health sector-based in SUS principles and guidances, this study aims to evaluate the essential attribute of Primary Health Care, longitudinally, in care directed at children from zero to two years old. 


\section{Methodology}

This study is part of the research entitled Development and validation of scale in the Childcare services: an evaluation study in Primary Health Care, which is a descriptive exploratory study of evaluative character and quantitative approach, performed with parents/caregivers of children under two years old using the Basic Units of Health services (UBS) in the city of Santa Cruz/RN, Brazil.

The sample was chosen for convenience, based on the record of the Family Health Units (USF) and the proportionality of registered patients, adopting allowable error of $5 \%$ and confidence level of $95 \%$, plus an $80 \%$ power by signing children's mothers to accept, with a sample of 186 children.

For data collection, the instrument Primary Care Assessment Tools (PCA Tools) was used, developed and validated by the Ministry of Health ${ }^{6}$ in the version for children, according to the foundations of APS, understood from the attributes of the health care system: first contact access, comprehensiveness, longitudinally, coordination, family and community orientation and cultural competencel. Thus, in this study, there are results concerning matters that deal with the longitudinal attribute.

Enrolled undergraduate students in Nursing at the Federal University and previously trained to conduct the interviews applied the questionnaires. The list of suitable participants for the sample was obtained from the City Health Department and, shortly after that, in the USF accompanying children. Interviews were conducted in USFs, with parents/caregivers who were in units for conducting childcare consultation, after explanation of the research objectives by the researchers, as well as reading and signing the consent form (TCLE) by parents/caregivers.

The collected data were stored and processed in Statistical Package for Social Sciences (SPSS) version 22.0, with serial number: 10101141047. Descriptive analysis (absolute-relative frequencies, mean, median, standard deviation) and chi-square test were held, considering a confidence interval (CI) of $95 \%$. The study was conducted after approval of the Research Ethics Committee (CEP) of the Trairí Health Sciences School, according to advocating Resolution 466/2012 of the National Health Council (CNS), on the research with human beings under number 348,896 .

\section{Results}

There were 186 parents/caregivers interviewed of children between zero and two years old, 106 male (57\%) and 80 female children (43\%). The average age of children in months was 8.21; the median was 7.00, and the standard deviation was 6.31. Regarding the mother's education, the average was 10.46 and the median of 9.00 years of study.

There were satisfactory values, according to Table 1 , when asked if the child was assisted by the same doctor/nurse at all times, where most of the sample said yes. About the doctor/nurse know the full medical history of the child, most of them said yes. Regarding the doctor/nurse know about all medications the child is taking, a large portion of the respondents said definitely yes.

Most of the respondents answered positively about the doctor/nurse having know- 
ledge about the family and socio-economic context of the child, and said that the professional knows the child as a person than only like someone with a health problem.

According to data in Table 2, the answers if the doctor/nurse would meet with members of the family, if necessary, revealed that just over half of the sample believes so; Almost half of respondents said the doctor/nurse do not know the family well, and a slightly less said the doctor/nurse do not know what are the most important problems for them.

A considerable portion said the doctor/nurse do not know about the work or employment of child's family members and; just under half said that certainly, yes, the doctor/nurse would know if they had problems getting or paying for medications that the child needs.

The data in Table 3 show that concerning the question if they could call and talk to the doctor/nurse if they had any questions about the health of the child, most of the participants responded negatively. Most of the interviewed found that the doctor/nurse understand what they say or ask. For an even larger portion of the interviewed, the

Table 1. Results of the validation of the longitudinal attribute construct (Knowledge of the children information) in Primary Health Care. Brazil, in 2015.

\begin{tabular}{|c|c|c|c|c|}
\hline \multirow[b]{2}{*}{ Variables } & \multicolumn{3}{|c|}{ Answers } & \multirow[b]{2}{*}{$\begin{array}{l}\text { Certainly, } \\
\text { yes }\end{array}$} \\
\hline & $\begin{array}{l}\text { Certainly, } \\
\text { no }\end{array}$ & $\begin{array}{l}\text { Probably, } \\
\text { no }\end{array}$ & $\begin{array}{c}\text { Probably, } \\
\text { yes }\end{array}$ & \\
\hline Same doctor/nurse assisting the child & $\begin{array}{c}7.0 \% \\
(\mathrm{n}=13)\end{array}$ & $\begin{array}{c}2.2 \% \\
(\mathrm{n}=4)\end{array}$ & $\begin{array}{c}5.4 \% \\
(\mathrm{n}=10)\end{array}$ & $\begin{array}{c}84.4 \% \\
(\mathrm{n}=157)\end{array}$ \\
\hline The doctor/nurse know the full medical history & $\begin{array}{c}8.1 \% \\
(\mathrm{n}=15)\end{array}$ & $\begin{array}{c}3.8 \% \\
(\mathrm{n}=7)\end{array}$ & $\begin{array}{c}4.8 \% \\
(n=9)\end{array}$ & $\begin{array}{c}81.7 \% \\
(\mathrm{n}=152)\end{array}$ \\
\hline $\begin{array}{c}\text { The doctor or nurse knows all medications the } \\
\text { children are taking }\end{array}$ & $\begin{array}{l}13.4 \% \\
(\mathrm{n}=25)\end{array}$ & $\begin{array}{c}0.5 \% \\
(\mathrm{n}=1)\end{array}$ & $\begin{array}{c}5.4 \% \\
(\mathrm{n}=10)\end{array}$ & $\begin{array}{c}75.3 \% \\
(\mathrm{n}=140)\end{array}$ \\
\hline $\begin{array}{l}\text { The doctor/nurse know the child more as a } \\
\text { person than as someone with health problems }\end{array}$ & $\begin{array}{c}8.6 \% \\
(n=16)\end{array}$ & $\begin{array}{c}4.3 \% \\
(\mathrm{n}=8)\end{array}$ & $\begin{array}{c}9.7 \% \\
(\mathrm{n}=18)\end{array}$ & $\begin{array}{c}73.7 \% \\
(\mathrm{n}=137)\end{array}$ \\
\hline
\end{tabular}

Table 2. Results of construct validation of the longitudinal attribute (professional and family relationship) in Primary Health Care. Brazil, in 2015.

\begin{tabular}{|c|c|c|c|c|}
\hline \multirow[b]{2}{*}{ Variables } & \multicolumn{3}{|c|}{ Answers } & \multirow[b]{2}{*}{$\begin{array}{c}\text { Certainly, } \\
\text { yes }\end{array}$} \\
\hline & $\begin{array}{c}\text { Certainly, } \\
\text { no }\end{array}$ & $\begin{array}{l}\text { Probably, } \\
\text { no }\end{array}$ & $\begin{array}{l}\text { Probably, } \\
\text { yes }\end{array}$ & \\
\hline $\begin{array}{l}\text { The doctor/nurse would meet with the family } \\
\text { if necessary }\end{array}$ & $\begin{array}{c}13.4 \% \\
(\mathrm{n}=25)\end{array}$ & $\begin{array}{c}5.4 \% \\
(\mathrm{n}=10)\end{array}$ & $\begin{array}{c}18.3 \% \\
(\mathrm{n}=34)\end{array}$ & $\begin{array}{c}55.9 \% \\
(\mathrm{n}=104)\end{array}$ \\
\hline The doctor / nurse knows the family well & $\begin{array}{c}48.9 \% \\
(\mathrm{n}=91)\end{array}$ & $\begin{array}{c}10.8 \% \\
(\mathrm{n}=20)\end{array}$ & $\begin{array}{c}7.5 \% \\
(\mathrm{n}=14)\end{array}$ & $\begin{array}{c}32.8 \% \\
(\mathrm{n}=61)\end{array}$ \\
\hline $\begin{array}{l}\text { The doctor/nurse knows the most important } \\
\text { problems of the family }\end{array}$ & $\begin{array}{c}45.7 \% \\
(\mathrm{n}=85)\end{array}$ & $\begin{array}{c}7.0 \% \\
(\mathrm{n}=13)\end{array}$ & $\begin{array}{c}10.8 \% \\
(\mathrm{n}=20)\end{array}$ & $\begin{array}{c}32.3 \% \\
(\mathrm{n}=60)\end{array}$ \\
\hline $\begin{array}{c}\text { The doctor/nurse know about the work and } \\
\text { employment of the family members }\end{array}$ & $\begin{array}{c}63.4 \% \\
(\mathrm{n}=118)\end{array}$ & $\begin{array}{c}4.3 \% \\
(\mathrm{n}=8)\end{array}$ & $\begin{array}{c}5.9 \% \\
(\mathrm{n}=11)\end{array}$ & $\begin{array}{c}26.3 \% \\
(\mathrm{n}=49)\end{array}$ \\
\hline $\begin{array}{l}\text { The doctor/nurse would know the problems of } \\
\text { getting or paying for medicines }\end{array}$ & $\begin{array}{c}33.9 \% \\
(\mathrm{n}=63)\end{array}$ & $\begin{array}{c}4.3 \% \\
(\mathrm{n}=8)\end{array}$ & $\begin{array}{c}11.3 \% \\
(\mathrm{n}=21)\end{array}$ & $\begin{array}{c}47.3 \% \\
(\mathrm{n}=88)\end{array}$ \\
\hline
\end{tabular}


Table 3. Results construct validation of longitudinal attribute (communication and trust between professionals and parents/caregivers) in Primary Health Care. Brazil, in 2015.

\begin{tabular}{|c|c|c|c|c|}
\hline \multirow{2}{*}{ Variables } & \multicolumn{3}{|c|}{ Answers } & \multirow[b]{2}{*}{ Certainly, yes } \\
\hline & Certainly, no & Probably, no & Probably, yes & \\
\hline $\begin{array}{c}\text { Can call the doctor/nurse to } \\
\text { ask questions }\end{array}$ & $\begin{array}{c}61.3 \% \\
(\mathrm{n}=114)\end{array}$ & $\begin{array}{c}7.0 \% \\
(\mathrm{n}=13)\end{array}$ & $\begin{array}{c}7.0 \% \\
(\mathrm{n}=13)\end{array}$ & $\begin{array}{l}20.4 \% \\
(\mathrm{n}=38)\end{array}$ \\
\hline $\begin{array}{c}\text { The doctor/nurse understand } \\
\text { what is said }\end{array}$ & $\begin{array}{l}2.2 \% \\
(\mathrm{n}=4)\end{array}$ & $\begin{array}{l}2.2 \% \\
(\mathrm{n}=4)\end{array}$ & $\begin{array}{c}8.6 \% \\
(\mathrm{n}=16)\end{array}$ & $\begin{array}{c}86.6 \% \\
(\mathrm{n}=161)\end{array}$ \\
\hline $\begin{array}{c}\text { The doctor/nurse answer } \\
\text { questions }\end{array}$ & $\begin{array}{l}1.1 \% \\
(\mathrm{n}=2)\end{array}$ & $\begin{array}{l}5.0 \% \\
(n=1)\end{array}$ & $\begin{array}{l}2.2 \% \\
(\mathrm{n}=4)\end{array}$ & $\begin{array}{c}96.2 \% \\
(\mathrm{n}=179)\end{array}$ \\
\hline $\begin{array}{l}\text { They have enough time to talk } \\
\text { about concerns and problems }\end{array}$ & $\begin{array}{l}1.1 \% \\
(\mathrm{n}=2)\end{array}$ & $\begin{array}{l}1.1 \% \\
(\mathrm{n}=2)\end{array}$ & $\begin{array}{l}1.6 \% \\
(\mathrm{n}=3)\end{array}$ & $\begin{array}{c}96.2 \% \\
(\mathrm{n}=179)\end{array}$ \\
\hline $\begin{array}{l}\text { They feel at ease telling } \\
\text { concerns and problems }\end{array}$ & $\begin{array}{l}1.6 \% \\
(\mathrm{n}=3)\end{array}$ & $\begin{array}{l}0.5 \% \\
(\mathrm{n}=1)\end{array}$ & $\begin{array}{l}1.1 \% \\
(\mathrm{n}=2)\end{array}$ & $\begin{array}{c}96.2 \% \\
(\mathrm{n}=179)\end{array}$ \\
\hline $\begin{array}{l}\text { They would change the } \\
\text { service/doctor/nurse to } \\
\text { another }\end{array}$ & $\begin{array}{c}66.7 \% \\
(\mathrm{n}=124)\end{array}$ & $\begin{array}{c}2.2 \% \\
(\mathrm{n}=4)\end{array}$ & $\begin{array}{c}2.7 \% \\
(\mathrm{n}=5)\end{array}$ & $\begin{array}{c}28.0 \% \\
(\mathrm{n}=52)\end{array}$ \\
\hline
\end{tabular}

doctor/nurse answer the questions for them to understand.

When asked if the doctor/nurse give enough time to talk about their concerns or problems, a large majority said yes, as well as a large portion of respondents said they feel comfortable telling the concerns or child-related problems to the doctor/nurse and; almost half of respondents claimed they would not change the service/doctor/nurse to another health service.

\section{Discussion}

This study considered the care provided to children in Primary Health Care from the evaluation of longitudinal attribute, according to the perception of parents/caregivers of children from 0 to 2 years old since it is important the estimate of performance of APS in the growth and development of the child, which contributes to the detection and prevention of future disorders as well as improvement in children quality of life.

The sample has characteristics similar to other studies [5] [6], which assessed children aged zero to two years old, concerning the proportion of female children and male and having higher mean age than the current study, 12.7 and 13.3 months, respectively.

From the average educational level of mothers, there is a good perspective on the understanding of these regarding the importance of childcare consultations and provides greater ease of communicating with health professionals. According to a study [7] conducted with 19 families of children treated at the APS service, some family members are not aware of the importance and purpose of the consultations. This factor can positively or negatively influence the effectiveness of longitudinal health of children.

In other studies evaluating the attribute in different APS services, there were satisfactory values in longitudinal actions [5] [6]. The data in Table 1 show that, also in this study, the longitudinal care is well characterized when considering the relationship 
established between professional and child, evidenced by the consultations held by the same professional, knowledge of the clinical history of the child by that professional, knowledge about the medications the child is taking and if professional knows the child more as a person than in a pathological aspect.

The construction of adequate health care to the child demands a greater interaction with the family, which provides information on experiences, present and plans regarding the child's life story [5] [8]. However, in Table 2, data show that in the aspect of the relationship between the professional and the child's family, the longitudinal care already becomes more difficult, as evidenced, for example, by the fact that almost half of the sample say that the health professionals do not know the family quite well, and more than half noted that they have no knowledge about the occupation of the family of the child they assist.

According to Smith et al. [9] this relationship is facilitated when there is common ground between the parents and professionals and when this professional takes a posture of non-judgment, informality, and solidarity because parents feel more comfortable and confident when they are at the "same level" of health professionals.

It is also emphasized that in situations where the bond established between the family and professionals is not satisfactory, the family have discomfort for the search for resolution of the child's health problem, however, they prefer the service with professionals able to understand them and to establish a closer and pleasant bond [10].

This confirms the importance of the interest by the professional to know the family and social context of the child and the health status, to maintain the bond and promotion of longitudinal care, since when it is not real, patients seek care with other professionals.

Therefore, some practices can be used for effective longitudinal care as speaking, listening, relationship and negotiation between professionals and patients, directing care to the population's needs [2].

Thus, it is important to allow parents/caregivers talk about their doubts, fears, desires and interests, giving enough time and instructed as to their questions because each child and each family has its peculiarities [8].

In this study, it was observed that communication between parents/caregivers and health professionals positively influence the longitudinal care. It is noticed that communication by telephone is possible for a minority of respondents. However, when it comes to the quality of communication-based face-to-face, this is well assessed by the vast majority of respondents, who report having enough time to report their questions, get clear answers from professionals as well as have enough time and feel free to talk about their concerns and problems, which demonstrates the inherent trust, favoring longitudinal care.

In a study of professionals and patients of primary health care services, it was found that the population recognizes the health units as responsible for providing their care and, therefore, health team feels responsible for presenting solving the health problems of the population [11]. For health professionals, the factors that favor the implementation 
of longitudinal care are: the need to provide comprehensive and resolute supportaccording to the SUS premises-focused on the family, which also brings the patients, gaining their trust and establishing more lasting bonds; Another point made by nurses is that teamwork favors the development of a long-term care, especially in the complementarity of actions among professionals [12].

In this study, for most parents/caregivers, APS service used meets the demand of health of the family, since when asked about the possibility of switching to another service, $66.7 \%$ responded that they would not change. The rest of the sample are not sure or said that would change to another health service if they could, looking for easier access to consultations, exams, and treatments, which is still a step to overcome in public health services.

Thus, it appears that the correlation between the actions of different professionals working in APS (Community health agents, dentists, nursing staff and doctors), also determines the true longitudinal practice, as a complement to thereby achieving the improvement in the quality of health and life of individuals.

In addition, longitudinal care is related to the host, which is a strategy to achieve it because the host sets up the good communication, which tends to encourage continuity of care, attracting the patient to the APS service and allowing to be a nice place for the establishment of a therapeutic, preventive care and health education [2].

\section{Conclusions}

It appeared that the longitudinal care is something that goes beyond the establishment of a long relationship between health professionals and patients, since it determines the building of a professional-patient relationship that promotes solving assistance to problems that interfere with the growth and development of children, from the knowledge of the socioeconomic and health family background.

Thus, it is concluded that this attribute was highly rated by the mothers of children seen in primary health care services and that they can establish good communication and relationship with the health professionals who treat their children.

Regarding the limitations of the study, there is the fact that it is a local study. However, it may represent the reality of other municipalities, serving to guide the completion of other studies with the same approach. The fact that the interviews were held at UBS, it may have induced some positive responses from the interviewees. However, it is observed, from the results, that even in this situation the sample said negative aspects of several questions.

\section{References}

[1] Starfiel, B. (2002) Atenção primária. Balancing Health Needs, Services and Technology. UNESCO, Ministério da Saúde (Brasília).

[2] Oliveira, M.A. and Pereira, I.C. (2013) Essential Attributes of Primary Care and the Family Health Strategy. Revista Brasileira de Enfermagem, 66, 158-164.

http://dx.doi.org/10.1590/S0034-71672013000700020

[3] Brazil. Ministry of Health. Secretary of Health Care. Basic Care Department (2009) 
Children's Health: Infant Nutrition: Breastfeeding and Complementary Feeding. Ministry of Health (Brasília).

[4] Brazil. Ministry of Health. Secretary of Health Care. Basic Care Department (2012) Children's Health: Growth and Development. Ministry of Health (Brasília).

[5] Leão, C.D., Caldeira, A.P. and Oliveira, M.M. (2011) Attributes of Primary Care in the Health Care of Children: Evaluation of Caregivers. Revista Brasileira de Saúde Materno Infantil, 11, 323-334. http://dx.doi.org/10.1590/S1519-38292011000300013

[6] Filho, M.M., Luz, B.S. and Araújo, C.S. (2014) Attention Primary Health Care and Their Attributes: The Situation of Children under Two Years after Their Caregiving. Ciênc Saúde Coletiva, 19, 2033-2046.

[7] Malaquias, T.S.M., Gaíva, M.A.M. and Higarashi, I.H. (2015) Perceptions the Family of Children on Child Care Consultation in the Family Health Strategy. Revista Gaúcha de Enfermagem, 36, 62-68. http://dx.doi.org/10.1590/1983-1447.2015.01.46907

[8] Mello, D.F., Furtado, M.C., Fonseca, L.M. and Pina, J.C. (2012) Follow Children's Health and Care Longitudinality. Revista Brasileira de Enfermagem, 65, 675-679. http://dx.doi.org/10.1590/S0034-71672012000400018

[9] Smith, E., Koerting, J., Latter, S., Knowles, M.M., McCann, D.C., Thompson, M., et al. (2014) Overcoming Barriers to Effective Early Parenting Interventions for Attention-Deficit Hyperactivity Disorder (ADHD): Parent and Practitioner Views. Child: Care, Health and Development, 41, 93-102. http://dx.doi.org/10.1111/cch.12146

[10] Baltor, M.R.R., Matos, A.P.K., Wernet, M., Ferreira, N.M.L.A. and Dupas, G. (2013) Family Perceptions of Children with Chronic Illness Face Relations with Health Professionals. Revista da Escola de Enfermagem da USP, 47, 808-814.

http://dx.doi.org/10.1590/S0080-623420130000400006

[11] Guiggi, L.A., Barreto, D.S. and Fajardo, A.P. (2014) Reflections of a Health Care Team and its enrolled population about Longitudinality of Care. Journal of Primary Health Care, 17, 244-254. http://aps.ufjf.emnuvens.com.br/aps/article/view/2155/809

[12] Baratiere, T. and Marcon, S.S. (2011) Identifying Work Conditions on the Nurse's Job for the Development of Longitudinal Care. UERJ Nursing Journal, 19, 212-217. http://www.facenf.uerj.br/v19n2/v19n2a07.pdf

\section{Submit or recommend next manuscript to SCIRP and we will provide best service for you:}

Accepting pre-submission inquiries through Email, Facebook, LinkedIn, Twitter, etc.

A wide selection of journals (inclusive of 9 subjects, more than 200 journals)

Providing 24-hour high-quality service

User-friendly online submission system

Fair and swift peer-review system

Efficient typesetting and proofreading procedure

Display of the result of downloads and visits, as well as the number of cited articles

Maximum dissemination of your research work

Submit your manuscript at: http://papersubmission.scirp.org/

Or contact ojn@scirp.org 